\title{
PENGARUH BIAYA OPERASIONAL, STRUKTUR MODAL DAN BIAYA TENAGA KERJA LANGSUNG TERHADAP PROFITABILITAS PADA PT. TOR GANDA CABANG MABAR MEDAN
}

\author{
Rebecca Evadine, Dina Rosmaneliana ${ }^{\bowtie}$ \\ Dosen Tetap STIE ITMI, Medan, Indonesia \\ Email: dheena.gaol@yahoo.com
}

DOI: https://doi.org/10.46880/methoda.Vol11No3.pp207-216

\begin{abstract}
Every company including PT. TOR GANDA of the Mabar Medan Branch is not free from problems that affect the increase or decrease in profit. Every company tries to get the maximum profit. The profit earned by the company will affect the survival of the company. The purpose of this study was to determine the effect of operational costs, capital structure and direct labor costs on profitability at the company PT. TOR GANDA of the Mabar Medan Branch. The type of research used in this research is descriptive research. The results obtained in this study indicate that simultaneously operating costs, capital structure and labor costs directly affect the profitability of PT. TOR GANDA of the Mabar Medan Branch with a significance level of 0.000. Partially, operational costs have no significant effect on profitability with a significance value greater than 0.05. While the capital structure and direct labor costs have a significant effect on profitability with a smaller significance value of 0.05. The value of Adjusted $R$ Square is 0.668, which means that $66.8 \%$ of the factors that influence profitability can be explained by independent variables, while the remaining 33.2\% is explained by other factors not examined in this study.
\end{abstract}

Keyword: Operational Cost, Capital Structure, Direct Labor Cost, Profitability.

\begin{abstract}
ABSTRAK
Setiap perusahaan termasuk PT. TOR GANDA Cabang Mabar Medan tak luput dari masalah yang mempengaruhi kenaikan ataupun penurunan laba. Setiap perusahaan berusaha untuk memperoleh laba yang maksimal. Laba yang diperoleh perusahaan akan berpengaruh pada kelangsungan hidup perusahaan tersebut. Tujuan penelitian ini untuk mengetahui adanya pengaruh biaya operasional, struktur modal dan biaya tenaga kerja langsung terhadap profitabilitas pada perusahaan PT. TOR GANDA Cabang Mabar Medan. Jenis penelitian yang digunakan dalam penelitian ini adalah penelitian deskriptif. Hasil yang didapat dalam penelitian ini menunjukkan bahwa secara simultan biaya operasional, struktur modal dan biaya tenaga kerja langsung berpengaruh terhadap profitabilitas pada PT. TOR GANDA Cabang Mabar Medan dengan tingkat signifikansi 0,000 . Secara parsial dapat dilihat bahwa biaya operasional tidak berpengaruh signifikan terhadap profitabilitas dengan nilai signifikansi lebih besar 0,05 . Sedangkan struktur modal dan biaya tenaga kerja langsung berpengaruh signifikan terhadap profitabilitas dengan nilai signifikansi lebih kecil 0,05. Nilai Adjusted R Square adalah 0,668 berarti 66,8\% faktorfaktor yang mempengaruhi profitabilitas dapat dijelaskan oleh variabel bebas sedangkan sisanya 33,2\% dijelaskan oleh faktor-faktor lain yang tidak diteliti dalam penelitian ini.
\end{abstract}

Kata Kunci: Biaya Operasional, Struktur Modal, Biaya Tenaga Kerja Langsung, Profitabilitas. 


\section{PENDAHULUAN}

Perkembangan dunia usaha saat ini semakin pesat. Pesatnya dunia usaha diikuti oleh pesatnya persaingan. Persaingan tersebut menyebabkan setiap perusahaan yang didirikan harus memiliki tujuan agar perusahaan terus dapat beroperasi dalam jangka waktu panjang. Tujuan perusahaan dapat tercapai apabila perusahaan dikelola dengan baik. Pada umumnya, suatu perusahaan memiliki target atau tujuan untuk dicapai, salah satu tujuan tersebut adalah untuk mendapatkan laba yang tinggi dengan meminimalkan pengeluaran biaya-biaya yang terjadi dalam proses produksi.

Perusahaan perlu mengetahui perkembangan usaha dari waktu ke waktu terhadap apa yang telah di capai perusahaan pada masa lalu, masa sekarang dan masa yang akan datang, sehingga diperlukan suatu tindakan korektif yang mengarah pada tujuan perusahaan. Besar kecilnya laba perusahaan dapat dilihat melalui laporan keuangan perusahaan dengan rasio profitabilitas. Profitabilitas digunakan perusahaan untuk mengetahui seberapa besar laba yang diperoleh perusahaan dan mengukur kemampuan perusahaan dalam menghasilkan laba dengan menggunakan sumber-sumber yang dimiliki perusahaan. Biaya operasional atau yang disebut juga dengan Operating Expenses merupakan sejumlah biaya yang harus dikeluarkan oleh suatu perusahaan untuk mendukung operasi atau kegiatan yang dilakukan oleh perusahaan tersebut. Biaya operasional biasanya dapat berupa biaya untuk penjualan dan administrasi untuk memperoleh pendapatan, serta tidak termasuk pada pengeluaran yang telah diperhitungkan dalam harga pokok penjualan maupun faktor penyusutan. Biaya operasional juga dapat diasumsikan sebagai biaya yang diperlukan untuk mengolah bahan baku menjadi produk siap jual. Biaya tenaga kerja langsung adalah biaya yang berhubungan langsung dengan kegiatan proses produksi dimulai dengan pengolahan bahan baku hingga menjadi produk jadi. Berbeda halnya dengan biaya tenaga kerja langsung dimana cenderung konstan, karena hampir seluruh perusahaan lebih mengutamakan penggunaan tenaga mesin daripada tenaga manusia. Perusahaan yang sedang berkembang menentukan modal mereka yang berasal dari hutang ataupun ekuitas. Keputusan pendanaan berkaitan erat dengan struktur modal, yaitu perbandingan antara hutang jangka panjang (modal asing) dengan modal sendiri.

Penggunaan hutang yang besar akan mengakibatkan semakin rendahnya profitabilitas, dimana penggunaan hutang yang besar akan mengakibatkan beban bunga yang tinggi dimana beban bunga tersebut akan menurunkan laba bersih sehingga profitnya menjadi rendah, maka hal itu dapat menyebabkan perusahaan bangkrut.

PT. TOR GANDA Cabang Mabar Medan adalah perusahaan yang bergerak dibidang perkebunan. Tujuan dari PT. TOR GANDA Cabang Mabar Medan adalah mampu meningkatkan laba dari tahun ke tahun. Apabila perusahaan telah mampu meningkatkan laba, maka perusahaan tersebut dapat dikatakan sebagai manajemen yang sukses. Setiap perusahaan termasuk PT. TOR GANDA Cabang Mabar Medan tak luput dari masalah yang dapat mempengaruhi kenaikan ataupun penurunan laba. Setiap perusahaan berusaha untuk memperoleh laba yang maksimal agar kelangsungan hidup perusahaan dapat terjamin, sehingga dapat selalu mengusahakan besarnya perkembangan lebih lanjut. Berdasarkan uraian yang telah disajikan, maka peneliti tertarik untuk melakukan penelitian mengenai pengaruh biaya operasional, struktur modal dan biaya tenaga kerja langsung terhadap profitabilitas pada PT. TOR GANDA Cabang Mabar Medan.

\section{TINJAUAN PUSTAKA}

\section{Biaya Operasional}

Biaya operasional atau biaya usaha (operating expenses) adalah biaya-biaya yang tidak berhubungan langsung dengan produk perusahaan tetapi berkaitan dengan aktivitas operasional perusahaan sehari-hari (Jusuf, 2017). Biaya usaha sering disebut juga dengan istilah SGA (selling, general, and administration expenses). 
Biaya operasional ini dapat dibagi menjadi 2 jenis (Jusuf, 2017), yakni:

1. Biaya penjualan (selling expenses), yaitu biaya yang berkaitan dengan penjualan. Misalnya biaya promosi, biaya pengemasan barang, biaya gaji, dan komisi penjualan para salesman, dan lain-lain.

2. Biaya administrasi dan umum (general and administration expenses), yaitu biaya-biaya yang tidak berhubungan dengan penjualan. Misalnya biaya gaji staf administrasi, biaya persediaan alat kantor, biaya penyusutan, gaji, dan lain-lain.

\section{Struktur Modal}

Struktur modal adalah perbandingan atau perimbangan pendanaan jangka panjang perusahaan yang ditunjukkan oleh perbandingan hutang jangka panjang dengan modal sendiri. Pengambilan keputusan mengenai jenis pembiayaan dan struktur permodalan suatu perusahaan memiliki peran penting dalam perusahaan. Keputusan yang tidak tepat mengenai struktur modal ini dapat menyebabkan keterbatasan keuangan, likuidasi dan kebangkrutan perusahaan. Oleh karena itu, dapat dikatakan bahwa keputusan mengenai jenis struktur modal yang dapat memungkinkan perusahaan untuk tetap stabil (Arasteh, Nourbakhsh, \& Pourali, 2013).

\section{Biaya Tenaga Kerja}

Biaya tenaga kerja langsung adalah kompensasi bagi seluruh tenaga kerja yang dianggap menjadi bagian dari tujuan biaya (seperti, barang jadi atau barang dalam proses) dan dapat dicatat dalam tujuan biaya tersebut dengan cara ekonomi yang mudah (Suadi, 2015).

\section{Teori Profitabilitas}

Profitabilitas adalah kemampuan suatu perusahaan untuk memperoleh laba dalam hubungannya dengan penjualan, total asset maupun total modal sendiri (Susilowati, 2011). Tingkat profitabilitas memperlihatkan kemampuan perusahaan untuk keuntungan dari investasi yang dilakukan. Hal ini dikarenakan perusahaan yang memiliki profitabilitas yang tinggi cenderung menggunakan hutang relatif kecil karena laba ditahan yang tinggi sudah memadai untuk membiayai sebagian besar kebutuhan pendanaan (Sartono, 2015)

\section{Kerangka Konseptual}

Berdasarkan uraian teoritis diatas maka penelitian ini dilakukan untuk memberi gambaran tentang pengaruh biaya operasional, struktur modal dan biaya tenaga kerja langsung pada PT. TOR GANDA Cabang Mabar. Maka kerangka pemikiran dalam penelitian ini adalah sebagai berikut:

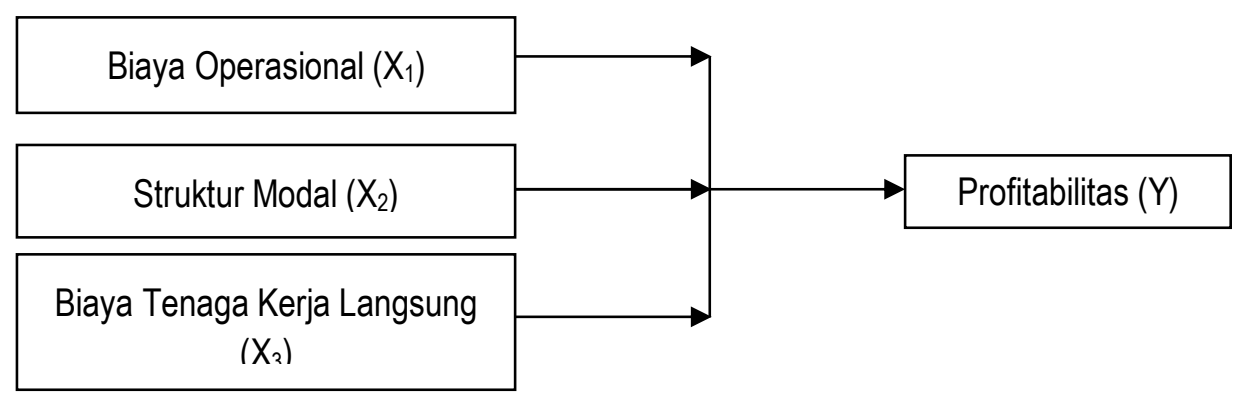

Gambar 1. Kerangka Konseptual

\section{METODOLOGI PENELITIAN}

\section{Objek Penelitian}

Penelitian ini dilaksanakan di PT. TOR GANDA Cabang Mabar Medan yang berlokasi di Jalan Mangaan 8 Gang Berdikari, Medan.
Teknik pengambilan sampel menggunakan metode purposive sampling yaitu teknik pengambilan sampel dengan pertimbangan tertentu atau disebut juga dengan penarikan sampel bertujuan. Populasi penelitian yaitu laporan keuangan PT. TOR GANDA Cabang Mabar tahun 2013-2015. Jumlah populasi dalam penelitian ini terbatas yaitu $12 \times 3$ tahun.

\section{Teknik Pengumpulan Data}


HASIL DAN PEMBAHASAN

\section{Statistik Deskriptif}

Statistik deskriptif ini memberikan gambaran mengenai nilai minimum, nilai maksimum, nilai rata-rata serta standar deviasi data yang digunakan dalam penelitian. Hasil pengelolahan data dari sampel dapat dilihat dari statistik deskriptif dibawah ini:

Tabel 1. Statistik Deskriptif

\begin{tabular}{|l|c|r|r|r|r|}
\hline & N & \multicolumn{1}{|c|}{ Minimum } & \multicolumn{1}{|c|}{ Maximum } & \multicolumn{1}{|c|}{ Mean } & \multicolumn{1}{c|}{ Std. Deviation } \\
\hline Biaya Operasional & 36 & 97243967560 & 143074514861 & 114973619232.06 & 14561061218.950 \\
Struktur Modal & 36 & 76178246504 & 98267071567 & 89011259916.78 & 5977662414.176 \\
Biaya Tenaga Kerja & 36 & 86711107032 & 111292378881 & 98742733438.17 & 3905338232.602 \\
Langsung & 36 & 149596372459 & 187299779901 & 166870739024.31 & 15400895884.527 \\
Profitabilitas & 36 & & & & \\
Valid N (listwise) & & & & \\
\hline
\end{tabular}

Sumber: Output SPSS

\section{Hasil Uji Asumsi Klasik}

\section{Uji Normalitas}

Uji normalitas bertujuan untuk menguji apakah dalam model regresi, variabel pengganggu atau residual memiliki distribusi normal. Uji Normalitas ini dapat dilihat dengan 2 (dua) cara yaitu dengan uji statistik dan analisis grafik.

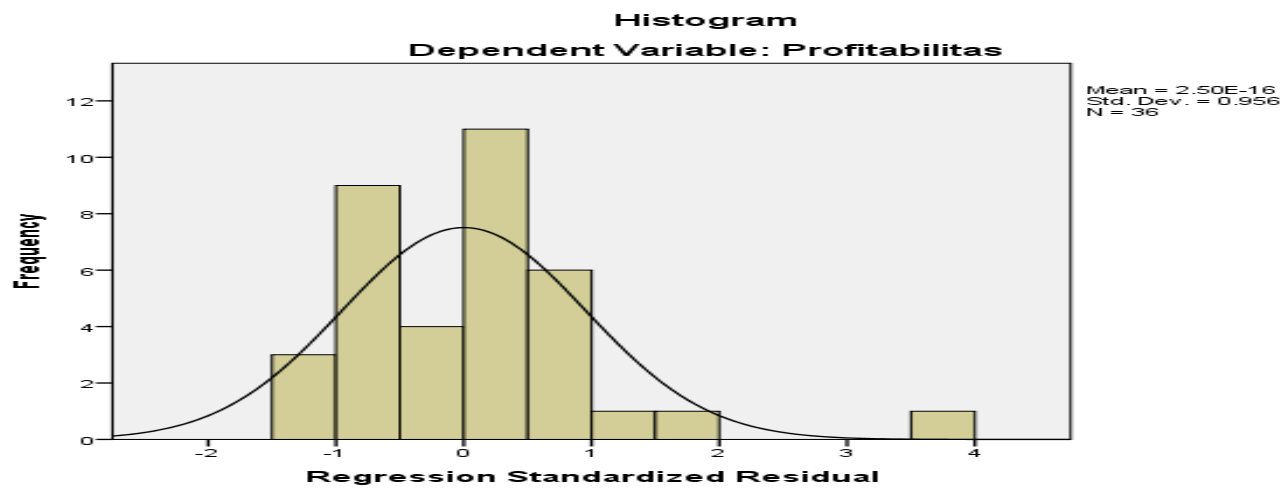

Sumber: Output SPSS

Gambar 1. Analisis Grafik Histogram

Berdasarkan gambar 1 hasil uji normalitas histogram menunjukkan data tidak terdistribusi menunjukkan data simetris atau garis lonceng normal, hal ini dapat dilihat dari grafik yang tidak menceng ke kanan atau ke kiri.

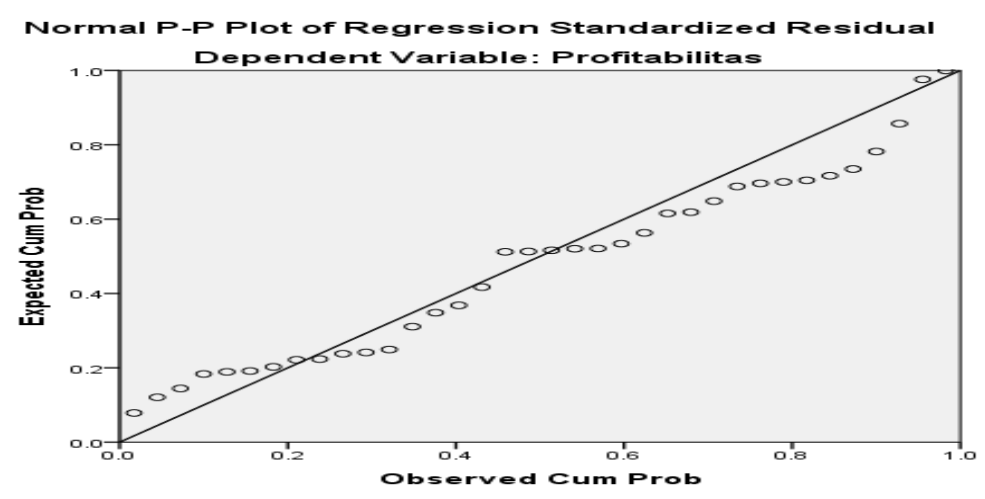

Sumber: Output SPSS

Gambar 2. Analisis Grafik Normal Probability Plot 
Grafik normal probability plot pada gambar 2 menunjukkan bahwa data menyebar disekitar garis diagonal dan mengikuti arah garis diagonal atau grafik histogramnya sehingga menunjukkan pola distribusi normal.

Tabel 2. One-Sample

Kolmogorov-Smirnov Test

\begin{tabular}{|c|c|c|}
\hline & & Unstandardized Residual \\
\hline $\mathrm{N}$ & & 36 \\
\hline & Mean & .0000029 \\
\hline Normal Parameters ${ }^{\mathrm{a}, \mathrm{b}}$ & Std. & 8877216174.45289200 \\
\hline & Deviation & \\
\hline & Absolute & .145 \\
\hline Most Extreme Differences & Positive & .145 \\
\hline & Negative & -.089 \\
\hline Kolmogorov-Smirnov Z & & .868 \\
\hline Asymp. Sig. (2-tailed) & & .438 \\
\hline
\end{tabular}

a. Test distribution is Normal.

b. Calculated from data.

Sumber: Output SPSS

Pada Tabel 2 di atas menunjukkan hasil uji statistik Kolmogorov Smirnov dapat dikatakan bahwa variabel biaya operasional (X1), struktur modal (X2), biaya tenaga kerja langsung (X3) dan profitabilitas $(\mathrm{Y})$ sudah memenuhi syarat distribusi normal karena nilai signifikan sebesar $0,438>0,05$ dikatakan bahwa model regresi ini layak digunakan untuk analisis.

\section{Uji Multikolinearitas}

Uji multikolinearitas bertujuan untuk menguji apakah pada model regresi ditemukan adanya korelasi antar variabel independen. Pada model regresi yang baik seharusnya tidak terjadi korelasi antar variabel independen. Pengujian multikolinearitas dilakukan dengan melihat VIF antar variabel independen.

Tabel 3.

Uji Multikolinearitas

Coefficients $^{\mathrm{a}}$

\begin{tabular}{|l|r|r|}
\hline \multirow{2}{*}{ Model } & \multicolumn{2}{|c|}{ Collinearity Statistics } \\
\cline { 2 - 3 } & Tolerance & \multicolumn{1}{|c|}{ VIF } \\
\hline \multicolumn{1}{|c|}{ (Constant) } & .156 & 6.426 \\
Biaya Operasional & .123 & 8.142 \\
Struktur Modal & .553 & 1.809 \\
\hline
\end{tabular}

a. Dependent Variable: Profitabilitas

Sumber: Output SPSS

Pada Tabel 3 di atas menunjukkan batas tolerance value adalah 0,1 dan batas VIF adalah 10. Apabila tolerance value $>0,1$ atau $\mathrm{VIF}<10$, maka tidak terjadi multikolinearitas. Nilai tolerance variabel biaya operasional, struktur modal dan biaya tenaga kerja langsung berada diatas 0,10 sedangkan nilai VIF variabel biaya operasional, struktur modal dan biaya tenaga kerja langsung berada dibawah 10. Dengan demikian dari hasil uji multikolinearitas dapat diambil kesimpulan tidak terjadi korelasi antar variabel independen. 


\section{Uji Autokorelasi}

Uji autokorelasi bertujuan untuk menguji apakah dalam suatu model regresi linear ada korelasi antar kesalahan pengganggu pada periode $\mathrm{t}$ dengan kesalahan pada periode $\mathrm{t}-1$ (sebelumnya).

Tabel 4. Uji Autokorelasi

Model Summary

\begin{tabular}{|l|r|r|r|r|r|}
\hline Model & \multicolumn{1}{c|}{$\mathrm{R}$} & R Square & Adjusted R Square & Std. Error of the Estimate & Durbin-Watson \\
\hline 1 & $.817^{\mathrm{a}}$ & .668 & .637 & 9284014900.083 & 2.234 \\
\hline
\end{tabular}

a. Predictors: (Constant), Biaya Tenaga Kerja Langsung, Biaya Operasional, Struktur Modal

b. Dependent Variable: Profitabilitas

Sumber: Output SPSS

Hasil Uji Autokorelasi diperoleh nilai DW sebesar 2,234 dengan demikian dengan melihat ketentuan pengambilan keputusan ada tidaknya autokorelasi dapat disimpulkan pada penelitian ini tidak terjadi autokorelasi positif dan negative karena nilai dw terletak diantara du dan 4-du atau $\mathrm{du}<\mathrm{dw}<4$-du atau $1,6539<2,234<2,3461$.

\section{Uji Heterokedastisitas}

Uji heterokedastisitas bertujuan untuk melihat apakah di dalam model regresi terjadi ketidaksamaan variabel dari residual suatu pengamatan ke pengamatan yang lain.

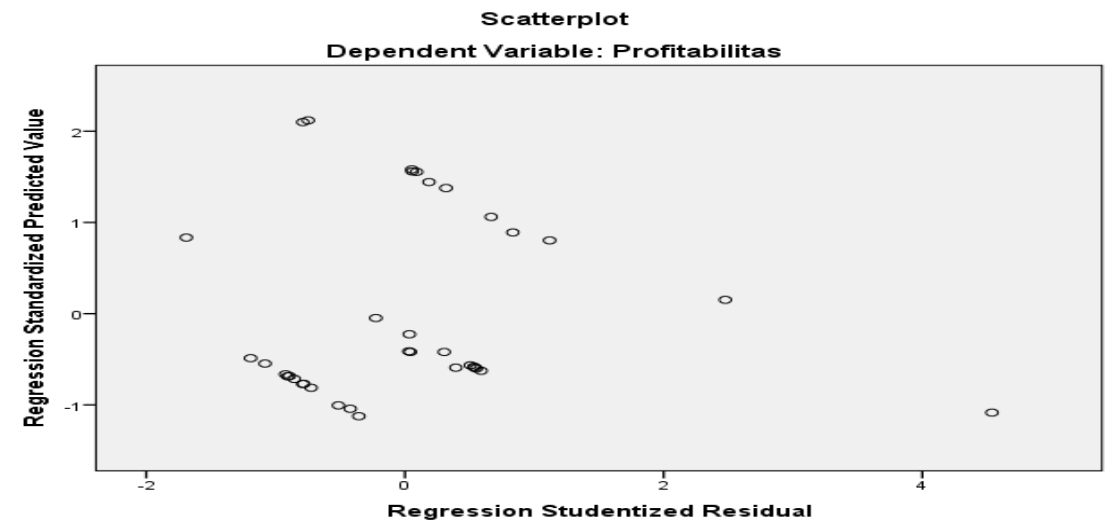

Sumber: Output SPSS

Gambar 3. Grafik Scatter Plot

Pada Gambar 3 untuk grafik scatterplot dapat dilihat bahwa titik-titik menyebar secara acak serta tersebar baik di atas maupun di bawah angka 0 pada sumbu Y. Hal ini dapat disimpulkan bahwa tidak terjadi heteroskedastisitas pada model regresi sehingga model regresi layak dipakai untuk menjawab hipotesis selanjutnya.

\section{Analisis Regresi Linear Berganda}

Tabel berikut ini menunjukkan hasil estimasi regresi linear berganda.

Tabel 5. Uji Persamaan Regresi

Coefficients $^{\mathrm{a}}$

\begin{tabular}{|c|c|c|c|c|c|}
\hline \multirow[t]{2}{*}{ Model } & \multicolumn{2}{|c|}{ Unstandardized Coefficients } & \multirow{2}{*}{$\begin{array}{c}\text { Standardized } \\
\text { Coefficients }\end{array}$} & \multirow[t]{2}{*}{$\mathrm{t}$} & \multirow[t]{2}{*}{ Sig. } \\
\hline & B & Std. Error & & & \\
\hline (Constant) & 100269098921.634 & 42060483298.544 & & 2.384 & .023 \\
\hline Biaya Operasional & -.256 & .273 & -.242 & -.938 & .355 \\
\hline
\end{tabular}




\begin{tabular}{|c|c|c|c|c|c|}
\hline Struktur Modal & 3.263 & .749 & 1.266 & 4.356 & .000 \\
\hline $\begin{array}{l}\text { Biaya Tenaga Kerja } \\
\text { Langsung }\end{array}$ & -1.968 & .540 & -.499 & -3.642 & .0 \\
\hline
\end{tabular}

a. Dependent Variable: Profitabilitas

Sumber: Output SPSS

Berdasarkan Tabel 5 maka diperoleh persamaan linear berganda untuk variabel Pendapatan usaha, Biaya operasional dan Perputaran total aktiva yang menjadi hipotesis penelitian ini sebagai berikut:

\section{$Y=100269098921,634-0,256 X_{1}+3,263 X_{2}-$ $1,968 \times 3$}

Maka makna persamaan regresi linear berganda diatas adalah:

1. Konstan sebesar 100269098921,634 berarti bahwa jika dipengaruhi oleh ketiga variabel bebas, maka peramalan (prediksi) profitabilitas akan cenderung positif sebesar 100269098921,634

2. Koefisien biaya operasional $\left(\mathrm{X}_{1}\right)$ diperoleh sebesar -0,256 yang berarti kenaikan biaya operasional akan dapat menurunkan peramalan (prediksi) profitabilitas sebesar 0,256 .

3. Koefisien struktur modal $\left(\mathrm{X}_{2}\right)$ diperoleh sebesar 3,268 yang berarti kenaikan struktur modal akan dapat menurunkan peramalan (prediksi) profitabilitas sebesar 3,268.

4. Koefisien biaya tenaga kerja langsung (X3) diperoleh sebesar $-1,968$ yang berarti kenaikan biaya tenaga kerja langsung akan dapat menurunkan peramalan (prediksi) profitabilitas sebesar $-1,968$.

\section{Pengujian Hipotesis Secara Parsial}

Pengujian parsial (Uji t) digunakan untuk mengetahui ada tidaknya hubungan atau pengaruh yang berarti (signifikan) antara variabel independen secara parsial terhadap variabel dependen.

Tabel 6. Uji Parsial (Uji t)

Coefficients $^{\mathrm{a}}$

\begin{tabular}{|l|r|r|r|r|r|}
\hline \multirow{2}{*}{ Model } & \multicolumn{2}{|c|}{ Unstandardized Coefficients } & \multicolumn{1}{c|}{$\begin{array}{c}\text { Standardized } \\
\text { Coefficients }\end{array}$} & \multicolumn{1}{c|}{$\mathrm{sig}}$. \\
\cline { 2 - 5 } & \multicolumn{1}{|c|}{$\mathrm{B}$} & Std. Error & \multicolumn{1}{c|}{ Beta } & \\
\hline (Constant) & 100269098921.634 & 42060483298.544 & & 2.384 & .023 \\
Biaya Operasional & -.256 & .273 & -.242 & -.938 & .355 \\
1 Struktur Modal & 3.263 & .749 & 1.266 & 4.356 & .000 \\
Biaya Tenaga Kerja & -1.968 & .540 & -.499 & -3.642 & .001 \\
Langsung & & & & \\
\hline
\end{tabular}

a. Dependent Variable: Profitabilitas

Sumber: Output SPSS

Berdasarkan hasil pengujian dengan menggunakan alat statistik untuk uji parsial atau uji t pada Tabel 6 dapat dijelaskan sebagai berikut:

1. Dari hasil estimasi variabel biaya operasional diperoleh nilai sig $>0.05$ maka $(0,355>$ 0,05), $\mathrm{H} 0$ diterima dan $\mathrm{H}_{1}$ ditolak.
2. Dari hasil estimasi variabel struktur modal diperoleh nilai sig $<0.05$ maka $(0,000<$ $0,05)$, $\mathrm{H} 0$ ditolak dan $\mathrm{H}_{2}$ diterima.

3. Dari hasil estimasi variabel biaya tenaga kerja langsung diperoleh nilai sig $<0,05$ maka $(0,001<0.05)$, H0 ditolak dan $\mathrm{H} 3$ diterima. 
Pengujian Hipotesis Secara Simultan

Pengujian secara simultan menggunakan Uji F.

Pengujian ini dilakukan untuk melihat seberapa besar pengaruh variabel independen secara bersama-sama terhadap variabel dependen.

Tabel 7. Uji Simultan (Uji F)

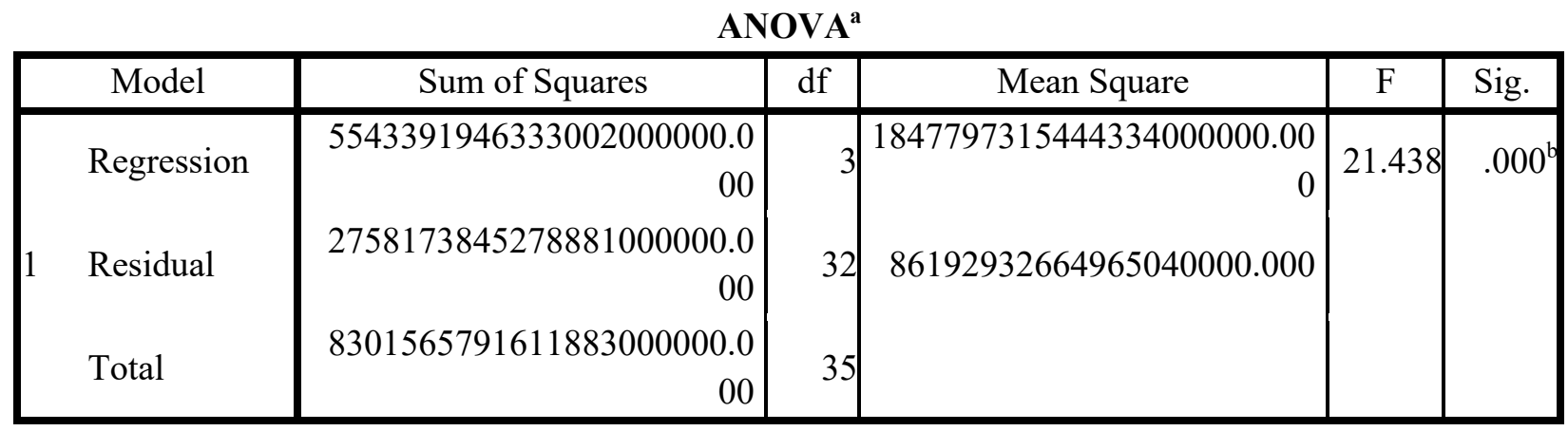

a. Dependent Variable: Profitabilitas

b. Predictors: (Constant), Biaya Operasional, Struktur Modal, Biaya Tenaga Kerja Langsung Sumber: Output SPSS

Uji signifikasi simultan (Uji F) menghasilkan nilai Fhitung sebesar 21,438. Pada derajat bebas $1(\mathrm{df1})=\mathrm{k}-1=4-1=3$, dan derajat bebas $2(\mathrm{df} 2)$ $=\mathrm{n}-\mathrm{k}=36-4=32$, dimana $\mathrm{n}=$ jumlah sampel, $\mathrm{k}$ $=$ jumlah variabel, nilai Ftabel pada taraf kepercayaan signifikasi 0,05 adalah 2,9 dengan demikian nilai Fhitung 21,438 $>\mathrm{F}$ tabel $=2$,9. Karena Fhitung lebih besar dari Ftabel dan probabilitasnya signifikan jauh lebih kecil dari 0,05. Maka Ha diterima artinya secara bersamasama biaya operasional, struktur modal dan biaya tenaga kerja langsung berpengaruh terhadap profitabilitas pada PT. TOR GANDA Cabang Mabar Medan periode 2013-2015.

\section{Koefisien Determinasi Hipotesis}

Uji koefisien determinasi ditujukan untuk mengetahui seberapa besar kemampuan model dalam menerangkan variabel dependen. Jika koefisien determinasi $\left(\mathrm{R}^{2}\right)$ semakin besar atau mendekati 1, maka dapat dikatakan bahwa kemampuan variabel independen (X) adalah kuat terhadap variabel dependen $(\mathrm{Y})$

Tabel 8. Uji Koefisien Determinasi

Model Summary ${ }^{\text {b }}$

\begin{tabular}{|l|r|r|r|r|}
\hline Model & R & R Square & Adjusted R Square & Std. Error of the Estimate \\
\hline 1 & $.817^{\mathrm{a}}$ & .668 & .637 & 9284014900.0083 \\
\hline
\end{tabular}

a. Predictors: (Constant), Biaya Operasional, Struktur Modal, Biaya Tenaga Kerja Langsung

b. Dependent Variable: Profitabilitas

Sumber: Output SPSS

Hasil uji koefisien determinasi diperoleh dari nilai $\mathrm{R}$ square sebesar 0,668 hal ini berarti $66,8 \%$ dari variansi variabel dependen profitabilitas yang dapat dijelaskan oleh variabel independen biaya operasional, struktur modal dan biaya tenaga kerja langsung.

Adapun hasil penelitian yang diperoleh adalah:

1. Pengaruh Biaya Operasional, Struktur Modal dan Biaya Tenaga Kerja Langsung Terhadap
Profitabilitas.

Dari hasil perhitungan diperoleh nilai Fhitung 21,438 $>$ Ftabel $=2,9$ dengan demikian $\mathrm{H} 4$ yang menyatakan biaya operasional, struktur modal dan biaya tenaga kerja langsung berpengaruh terhadap profitabilitas pada PT. TOR GANDA Cabang Mabar Medan periode 2013-2015 dapat diterima. Jika perusahaan ingin meningkatkan profitabilitas maka dapat 
dilakukan dengan cara meminimalkan biaya operasional. Namun apabila perusahaan telah berhasil meminimalkan biaya operasional namun dilain sisi tidak dapat menekan biaya tenaga kerja langsung maka profitabilitas yang diperoleh tidak dapat maksimal sehingga struktur modal mengalami kenaikan karena tidak dapat menutupi biaya tenaga kerja langsung.

2. Pengaruh Biaya Operasional Terhadap Profitabilitas.

Dari hasil signifikasi diperoleh $(0,355>0,5)$ dengan demikian $\mathrm{H} 1$ yang menyatakan biaya operasional berpengaruh terhadap profitabilitas pada PT. TOR GANDA Cabang Mabar Medan periode 2013-2015. Setiap perusahaan dalam menjalankan aktivitasnya pasti mempunyai tujuan utama yaitu mencapai laba semaksimal mungkin dengan biaya seminimal mungkin. Dalam suatu perusahaan, biaya merupakan salah satu komponen yang sangat penting. Oleh karena itu, biaya harus medapatkan perhatian yang lebih khusus. Dalam hal ini perusahaan harus mampu menjaga kekonsistenan perolehan laba dan mengontrol besarnya biaya operasional.

3. Pengaruh Struktur Modal Terhadap Profitabilitas.

Dari hasil signifikasi diperoleh $0,000<0,5$ dengan demikian $\mathrm{H} 2$ yang menyatakan struktur modal berpengaruh terhadap profitabilitas pada PT. TOR GANDA Cabang Medan periode 2013-2015 dapat diterima. Hasil persamaan regresi menunjukkan setiap kenaikan struktur modal mengakibatkan kenaikan profitabilitas.

4. Pengaruh Biaya Tenaga Kerja Langsung Terhadap Profitabilitas.

Dari hasil signifikasi diperoleh $0,001<0,5$ dengan demikian $\mathrm{H} 3$ yang menyatakan biaya tenaga kerja langsung berpengaruh terhadap profitabilitas pada PT. TOR GANDA Cabang Mabar Medan periode 2013-2015 dapat diterima.

\section{KESIMPULAN DAN SARAN}

Dari hasil penelitian diperoleh simpulan sebagai berikut:

1. Biaya operasional tidak berpengaruh terhadap profitabilitas pada PT. TOR GANDA Cabang Mabar Medan periode 2013-2015 dengan tingkat signifikan 0,335 > 0,05 .

2. Struktur modal berpengaruh positif dan signifikan terhadap profitabilitas pada PT. TOR GANDA Mabar Medan periode 20132015 dengan tingkat signifikan $0,000<0,5$.

3. Biaya tenaga kerja langsung berpengaruh negatif dan signifikan terhadap profitabilitas pada PT. TOR GANDA Mabar Medan periode 2013-2015 dengan tingkat signifikan $0,001<0,05$.

4. Biaya operasional tidak berpengaruh terhadap profitabilitas tetapi struktur modal dan biaya tenaga kerja langsung berpengaruh terhadap profitabilitas dan signifikan terhadap profitabilitas pada PT. TOR GANDA Mabar Medan periode 2013-2015 dengan tingkat signifikan $<0,05$.

Saran yang dapat diberikan dari hasil penelitian ini adalah:

1. Berdasarkan hasil penelitian ternyata biaya operasional tidak berpengaruh signifikan terhadap profitabilitas. Oleh karena itu perusahaan hendaknya terus berupaya meminimalisir biaya operasional seefisien mungkin untuk meningkatkan profitabilitas perusahaan.

2. Besarnya biaya tenaga kerja kerja langsung berpengaruh signifikan terhadap profitabilitas. Disarankan untuk mengurangi jumlah biaya untuk meminimalisasi resiko berkurangnya tingkat profitabilitas pada perusahaan tersebut.

3. Besarnya struktur modal berpengaruh signifikan terhadap profitabilitas. Berdasarkan hasil penelitian ini diharapkan dapat dijadikan sebagai dasar referensi bagi para pemilik modal untuk melakukan analisa pada faktor-faktor lain untuk meminimalisasi resiko terhadap investasinya.

4. Berdasarkan hasil penelitian ternyata biaya operasional tidak berpengaruh signifikan 
terhadap profitabilitas tetapi biaya tenaga kerja langsung dan struktur modal berpengaruh signifikan terhadap profitabilitas. Bagi peneliti selanjutnya diharapkan untuk menambah jumlah tahun yang akan diteliti untuk memperkuat hasil penelitian. Peneliti selanjutnya dapat menggunakan variabel bebas lainnya karena masih banyak faktor lainnya yang dapat mempengaruhi tingkat profitabilitas.

\section{DAFTAR PUSTAKA}

Arasteh, F., Nourbakhsh, M. M., \& Pourali, M. R. (2013). The study of relationship between capital structure, firm growth and financial strength with financial leverage of the company listed in Tehran stock exchange. Nterdisciplinary Journal of Contemporary Research in Business, 5(7), 480-491.

Devi, N. L. L. S., \& Merlina, I. G. N. A. S., (2016). Pengaruh Profitabilitas dan Solvabilitas Terhadap Ketepatan Waktu Dengan Reputasi Kantor Akuntan Publik sebagai Pemoderasi. E-Jurnal Akuntansi, 7(1), 395-425.

Ghozali, I. (2012). Aplikasi Analisis Multivariate dengan Program IBM SPSS 20 (Edisi 6). Semarang: Universitas Diponegoro Press.

Jusuf, J. (2017). Analisis Kredit untuk Credit (Account) Officer. Jakarta: PT. Gramedia Pustaka Utama.

Kasmir. (2012). Analisis Laporan Keuangan. Jakarta: Rajawali Pers.

Oktavia, E. (2011). Pengaruh Struktur Modal terhadap Profitabilitas pada UMKM. Universitas Negeri Medan

Sartono, R. A. (2015). Manajemen Keuangan Teori dan Aplikasi (Edisi 4). Yogyakarta: BPEE.

Suadi, A. (2015). Akuntansi Biaya (Edisi 2). Jakarta: Salemba Empat.

Susilowati, Y., \& Turyanto, T. (2011). Reaksi signal rasio profitabilitas dan rasio solvabilitas terhadap return saham perusahaan. Dinamika Keuangan Dan Perbankan, 3(1), 17-37. 